\title{
Impact of animal manure EM-bokashi on seed yield and quality of vegetable cowpea (Vigna unguiculata L.)
}

\author{
R. N. M. Shahardeen and T. H. Seran* \\ Department of Crop Science, Faculty of Agriculture, Eastern University, Chenkalady, Sri Lanka
}

\begin{abstract}
The study was undertaken to investigate the effect of EM treated animal manures (named as animal manure EM-bokashi) on yield and nutritional composition of seeds of vegetable cowpea (Vigna unguiculata L.). This experiment was carried out with five treatments and 15 replications. The pots were arranged in a completely randomized way in the net house. The treatments included a non-fertilizer application as a control, the recommended chemical fertilizer dose and three types of animal manure EM-bokashi (cattle manure EM-bokashi, goat manure EM-bokashi and poultry manure EM-bokashi). The results showed that application of EM treated animal manures significantly increased the number of leaves caused greater nodulation, produced higher number of pods per plant, yielded maximum number of seeds per pod, greater 100 seed weight, higher yield and increased seed quality compared to chemical and non-fertilizer treatments. Among the different types of animal manure EM-bokashi, goat manure EM-bokashi applied plants produced comparatively higher seed yield with good nutritional value in the present study thus it is most suitable for obtaining higher economic yield and better seed quality of vegetable cowpea on sandy regosol.
\end{abstract}

Keywords: Vegetable cowpea; Animal manure EM-bokashi; Seed yield and Quality

\section{Introduction}

Conventional agriculture is greatly dependant on chemical fertilizers which cause problems related to human health and environmental degradation and the problems has motivated researchers to find alternatives to chemical fertilizer (Chen, 2008). Effective and widespread use of organic fertilizers has great promise as a source of multiple nutrients and ability to improve soil characteristics (Moller, 2009). It can substantially reduce chemical fertilizer use without detrimentally affecting crop yields and can even serve to stabilize global crop prices (Alex, 2009). Making compost is an effective way to recycle organic waste into a useful one however, it takes longer period for full decomposition into available nutrients to the plants hence. Bokashi (organic matter fermented with effective microbes) is alternative to it (Anon, 1995).

EM-bokashi is an effective organic fertilizer in nature farming crop production (Kyan et. al., 1999). This type of farming provides several benefits to the growers and it is an environmental friendly method of cultivation. Further, organic manures contain many plant nutrients (nitrogen, phosphorus, potassium and many other essential nutrients) and it also increases infiltration of water and enhances retention of nutrients, reduces wind and water erosion and promotes growth of beneficial organisms (Ross, 2008).

Vegetable cowpea is grown by resource-poor farmers (Ano, 2006). It plays a critical role in the lives of millions of people in Africa and other parts of the developing world where it is a major source of dietary protein that nutritionally complements staple low-protein cereal and tuber crops and is a valuable and dependable commodity that produces income for farmers and traders (Langyintuo et. al., 2003). Moreover, pods are a rich source of calcium, magnesium, potassium and iron and high in nutrients and therefore, nutritionally the most acceptable for consumption; further, it has one of the highest levels of any food of folic acid and a crucial vitamin B that helps prevent spinal tube defects in unborn children (Omueti et. al., 2008).

EM produces greater quantities of better quality crops and enhances crop yields in organic systems in most environments (Kyan et. al., 1999). The research works have been done by various scientists in different countries in the field of agriculture using EM technology to various crops. However, there is limited information on use of EM technol- 
ogy to legume crops particularly vegetable cowpea with reference to seed production. The growers need quality seeds for their cultivation therefore, an attempt was made to study the effect of EM treated animal manure bokashi on seed yield and quality of vegetable cowpea on a sandy regosol.

\section{Materials and method}

\section{Environmental condition}

The experiment was conducted in 2009/2010 at the net house. It is located between $81^{\circ} 34^{\prime}$ latitude and longitude $7^{\circ} 48^{\prime}$ at the Eastern region of Sri Lanka. The soil of an experimental site is sandy regosol. The area receives a annual mean temperature of $28^{\circ}$ to $34^{\circ} \mathrm{C}$ and the mean rainfall is $1600 \mathrm{~mm}$ to $2100 \mathrm{~mm}$ and the humidity is $60 \%$ to $90 \%$.

\section{Preparation of EM solution}

EM super ${ }^{\mathrm{TM}}$ (SEEDS Ltd, Sri Lanka), molasses and pure water at the ratio of 1:1:100 (v/v/v) as recommended by Kyan et. al. (1999) were mixed and poured into clean plastic container to prepare EM solution. For the fermentation process, this mixture was kept under air tight dark condition for two days before preparation of the EM bokashi.

\section{Preparation of animal manure EM-bokashi}

As recommended by the Kyan et. al. (1999), animal manure, rice bran and paddy husk at the ratio of $2: 1: 1(\mathrm{w} / \mathrm{w} / \mathrm{w})$ respectively were used to prepare EM-bokashi. Different animal manures such as cattle, poultry and goat manures were used to prepare different types of EM-bokashi, but other materials used were same. EM solution already prepared was sprayed onto the dry ingredients (animal manure, rice bran and paddy husk) and mixed well until the moisture content reached within a range of $30-40 \%$. Mixture was heaped on a dry floor to a height of $15-20 \mathrm{~cm}$ and covered with a gunny bag. The temperature was maintained at $40 \pm$ $5^{\circ} \mathrm{C}$ during fermentation and was checked regularly. When bokashi had a sweet fermented smell it was ready for use. This was used after ten days of the preparation.

\section{Experimental design}

This study was done in a Complete Randomized Design (CRD) with five treatments and 15 replications. Treatments included a non-fertilizer application as a control $\left(\mathrm{T}_{1}\right)$, the recommended chemical fertilizer dose $\left(T_{2}\right)$, cattle manure EM-bokashi $\left(\mathrm{T}_{3}\right)$, goat manure EM-bokashi $\left(\mathrm{T}_{4}\right)$ and poultry manure EM-bokashi $\left(\mathrm{T}_{5}\right)$ application.

\section{Agronomic practices}

Red soil and sandy soil at a ratio of 1:1 were mixed thoroughly and it was filled into a polythene bag $(25 \mathrm{~cm}$ diameter) up to the height of $30 \mathrm{~cm}$. The 75 polythene bags were filled separately and arranged at the space of $20 \mathrm{~cm} \times 60 \mathrm{~cm}$. Chemical fertilizer recommended by the Department of Agriculture of Sri Lanka was used as a basal $(0.54 \mathrm{~g}$ of urea, $1.56 \mathrm{~g}$ of triple super phosphate and $0.76 \mathrm{~g}$ of muriate of potash applied to each bag) for vegetable cowpea cultivation. The different types of EM-bokashi at the rate of 300 $\mathrm{g} / \mathrm{m} 2$ was applied 14 days before sowing as basal and top dressing for field crop in the tropical regions as recommended by the Kyan et. al., (1999). The bags in all five treatments were seeded with seeds of cowpea variety cv BS1. At the 30th day after seeding, the same amount of EM-bokashi for $\mathrm{T}_{3}, \mathrm{~T}_{4}$ and $\mathrm{T}_{5}$ treatments and $0.54 \mathrm{~g}$ of urea for each bag in $\mathrm{T}_{1}$ treatment were added as top dressing. After planting, watering was done regularly and weeds were removed.

\section{Measurements}

Number of leaves per plant was counted at regular intervals and number of nodules, number of yellow pods and number of seeds were counted. Then fresh weight of nodules, fresh weight of yellow pods and their seed weight were recorded separately by using an electronic balance. After drying in an oven at $105^{\circ} \mathrm{C}$ overnight, weight of nodules was measured. Air dry weights of mature pods and seeds per plant as well as 100 seeds weight were also recorded. Finally seeds were subjected to proximate analysis for the parameter such as moisture, ash, crude fiber and protein contents using the methods described in AOAC (2002).

\section{Statistical analysis of data}

The collected data were analyzed statistically using SAS package. Data were first subjected to Shaio-Wilk test at $\mathrm{p}=0.05$ for normality before analysis of variance and log and square root transformation techniques were subjected on data wherever necessary. The means were compared using Duncan's Multiple Range Test at 5\% significant level.

\section{Results and discussion}

\section{Leaf formation}

The effects of EM-bokashi, chemical fertilizer and no-fertilizer on the number of leaves of vegetable cowpea at different week intervals are shown in Table I. Results demonstrate that the number of leaves increased significantly in all EM- 
bokashi treatments as compared to chemical fertilizer and no-fertilizer applications. Samina et. al. (2008) reported that the magnitude of stimulation was the maximum due to combined effect of EM-bokashi and farm yard manure on number of leaves of radish.

Table I. Effect of different treatments on number of leaves of vegetable cowpea

\begin{tabular}{lccc}
\hline & \multicolumn{3}{c}{ Number of leaves per plant } \\
\cline { 2 - 4 } Treatments & 3 weeks & 6 weeks & 9 weeks \\
\hline $\mathrm{T}_{1}$ & $4.2 \pm 0.13 \mathrm{~d}$ & $08.66 \pm 0.21 \mathrm{~b}$ & $4.66 \pm 0.33 \mathrm{~b}$ \\
$\mathrm{~T}_{2}$ & $4.6 \pm 0.16 \mathrm{~cd}$ & $08.83 \pm 0.16 \mathrm{~b}$ & $5.66 \pm 0.23 \mathrm{~b}$ \\
$\mathrm{~T}_{3}$ & $5.6 \pm 0.16 \mathrm{~b}$ & $11.16 \pm 0.40 \mathrm{a}$ & $7.00 \pm 0.57 \mathrm{a}$ \\
$\mathrm{T}_{4}$ & $6.8 \pm 0.13 \mathrm{a}$ & $11.83 \pm 0.16 \mathrm{a}$ & $8.33 \pm 0.33 \mathrm{a}$ \\
$\mathrm{T}_{5}$ & $5.2 \pm 0.13 \mathrm{bc}$ & $10.83 \pm 0.30 \mathrm{a}$ & $6.33 \pm 0.33 \mathrm{a}$ \\
$\mathrm{F}$ test & $*$ & $*$ & $*$ \\
CV\% & 9.1 & 7.5 & 10.6 \\
\hline
\end{tabular}

Value represents mean \pm standard error of two independent experiments, each having three replicates. $\mathrm{F}$ test:-*: $\mathrm{P}<0.05$

Means followed by the same letter in each column are not significantly different according to DMRT at 5\% level.

\section{Nodulation}

The result showed that the number and weights of nodules varied significantly $(\mathrm{P}<0.05)$ among the treatments (Table II). The greater increase in number and weight of nodules were observed in goat manure EM-bokashi treated plants following poultry manure EM-bokashi treated plants. Nofertilizer application treatment had the low nodule number and weights. This result agrees with Yan and Xu (2002) who found that EM-bokashi fertilizer significantly increased the nodule numbers per peanut plant. Similar response of nodulation to EM has also bean reported by Javaid et. al. (1999) in Phaseolus vulgaris and Vigna radiata. Sangakkara et. al.

Table II. Effect of different treatments on nodulation of vegetable cowpea at harvest

\begin{tabular}{lccc}
\hline & \multicolumn{3}{c}{ Nodules per plant } \\
\hline Treatments & Number & Fresh weight $(\mathrm{g})$ & Dry weight $(\mathrm{g})$ \\
\hline $\mathrm{T}_{1}$ & $09.00 \pm 0.57 \mathrm{c}$ & $0.09 \pm 0.01 \mathrm{c}$ & $0.01 \pm 0.00 \mathrm{~b}$ \\
$\mathrm{~T}_{2}$ & $12.66 \pm 0.88 \mathrm{bc}$ & $0.14 \pm 0.03 \mathrm{c}$ & $0.02 \pm 0.01 \mathrm{~b}$ \\
$\mathrm{~T}_{3}$ & $17.33 \pm 0.33 \mathrm{~b}$ & $0.56 \pm 0.05 \mathrm{~b}$ & $0.06 \pm 0.02 \mathrm{ab}$ \\
$\mathrm{T}_{4}$ & $30.66 \pm 2.66 \mathrm{a}$ & $1.13 \pm 0.08 \mathrm{a}$ & $0.15 \pm 0.03 \mathrm{a}$ \\
$\mathrm{T}_{5}$ & $25.00 \pm 1.00 \mathrm{a}$ & $0.88 \pm 0.03 \mathrm{a}$ & $0.07 \pm 0.03 \mathrm{ab}$ \\
$\mathrm{F}$ test & $*$ & $*$ & $*$ \\
$\mathrm{CV} \%$ & 10.9 & 16.1 & 16.6 \\
\hline
\end{tabular}

Value represents mean \pm standard error of two independent experiments, each having three replicates. $\mathrm{F}$ test:-*: $\mathrm{P}<0.05$.

Means followed by the same letter in each column are not significantly different according to DMRT at 5\% level.
(2008) stated that the EM had a greater beneficial effect in enhancing nitrogen availability of all composts, thus reducing $\mathrm{C}: \mathrm{N}$ ratio to a greater extent. The dry matter yield, nodule parameters and total nitrogen accumulation in the plant increased with increasing K supply (Premaratne and Oertli, 1994). Potassium is high in goat manure (Hsieh and Hsieh, 1990). It may be the reason for the higher nodulation rate in goat manure EM-bokahi.

\section{Number of pods}

The effect of different treatments on number of mature yellow pods per plant is shown in Table III. The higher number of pods per plant was recorded in the application of goat manure EM-bokashi (11) and lower number of pods per plant was found in non-fertilizer application treatment (6.25). According to this result, bokashi treatments expressed the higher pods per plant than chemical and control treatments. Many workers have reported increase in crop growth and yield by the application of EM (Yan and Xu, 2002; Khaliq et. al., 2006).

Table III. Effect of different treatments on numbers of mature yellow pods and seeds per plant at harvest

\begin{tabular}{lccc}
\hline Treatments & Number & Number & 100 seeds \\
\cline { 2 - 4 } & of pods per plant & of seeds per pod & weight $(\mathrm{g})$ \\
\hline $\mathrm{T}_{1}$ & $06.25 \pm 0.75 \mathrm{~b}$ & $08.18 \pm 0.59 \mathrm{~b}$ & $13.28 \pm 0.11 \mathrm{~d}$ \\
$\mathrm{~T}_{2}$ & $07.00 \pm 0.81 \mathrm{~b}$ & $08.66 \pm 0.27 \mathrm{~b}$ & $15.34 \pm 0.04 \mathrm{c}$ \\
$\mathrm{T}_{3}$ & $08.50 \pm 1.04 \mathrm{ab}$ & $11.35 \pm 0.41 \mathrm{a}$ & $17.45 \pm 0.65 \mathrm{~b}$ \\
$\mathrm{~T}_{4}$ & $11.00 \pm 0.81 \mathrm{a}$ & $12.00 \pm 0.19 \mathrm{a}$ & $18.74 \pm 0.17 \mathrm{a}$ \\
$\mathrm{T}_{5}$ & $09.50 \pm 0.28 \mathrm{ab}$ & $11.77 \pm 0.43 \mathrm{a}$ & $17.54 \pm 0.60 \mathrm{~b}$ \\
$\mathrm{~F}$ test & $*$ & $*$ & $*$ \\
CV\% & 19.7 & 10.7 & 1.4 \\
\hline
\end{tabular}

Value represents mean \pm standard error of two independent experiments, each having three replicates. $\mathrm{F}$ test:- ${ }^{*}: \mathrm{P}<0.05$.

Means followed by the same letter are not significantly different according to DMRT at 5\% level.

Number of seeds

The plants treated with the EM-bokashi $\left(\mathrm{T}_{3}, \mathrm{~T}_{4}\right.$ and $\left.\mathrm{T}_{3}\right)$ showed the higher number of seeds per pod and were significantly varied $(\mathrm{P}<0.05)$ from the chemical and non-fertilizer application treatment (Table III). This is in conformity of repots by Iwaishi (2000) who showed that EM inoculation increased kernel enlargement after the panicle formation stage and also increased ear number and length and kernel number in paddy. In present study, goat manure bokashi showed highest number of seeds per pod (12) within the EMbokashi treatments. This may be due to goat manure applied plant that formed highest number of nodules than other treatments. Sanginga et. al. (1994) who reported that increased nodulation give the higher pod yield. 


\section{0 seed weight}

Table III showed the 100 seed weight on different treatments. Goat manure EM-bokashi treatment showed high significant variation $(\mathrm{P}<0.01)$ among the treatments. bokashi treatments had high mean value from chemical and non-fertilizer application treatments. Non fertilizer application showed the lowest 100 seed weight. This trend of result is very much similar with those of Winget and Gold (2007) who observed that the plants treated with EM-bokashi showed the heaviest biomass of seed and were significantly heavier than chemical and control treatments. In the present study, goat manure-EM-bokashi showed the highest 100 seed weight and they produced high amount of nodules in the treated plants. It may be due to that consist of more potassium than others as reported by Hsieh and Hsieh (1990). Milev and Genchev (1996) showed that the positive correlation was found between the size of seeds, seed color and the nodule formation ability.

\section{Yield}

Pod yield of the vegetable cowpea after harvesting was showed in Table IV. Fresh and air dry weights of mature yellow pods showed no significant variation among the EMbokashi treatments $\left(T_{3}, T_{4}\right.$ and $\left.T_{5}\right)$, between them $T_{4}$ showed slightly higher pod yield than $\mathrm{T}_{3}$ and $\mathrm{T}_{5}$. Therefore, EMbokashi treatments expressed more pod yield than chemical and non fertilizer application treatments. EM was responsible for much of the yield increase, possibly due to increased availability of plant nutrients or direct beneficial effects on plant growth, health and protection (Stolze et. al. 2000). Many researches reported yield increases due to the use of EM in combination with animal residues have been reported on various crops such as onion production (Myint, 1991).

Table IV. Effect of different treatments on yield of vegetable cowpea at harvest

\begin{tabular}{|c|c|c|c|}
\hline \multirow{3}{*}{ Treatments } & \multicolumn{3}{|c|}{ Yield per plant (g) } \\
\hline & \multicolumn{2}{|c|}{ Mature yellow pod yield } & Mature Seeds yield \\
\hline & Fresh weight & Air dry weight & Air dry weight \\
\hline $\mathrm{T}_{1}$ & $15.96 \pm 2.31 \mathrm{c}$ & $09.34 \pm 1.39 \mathrm{c}$ & $06.90 \pm 0.05 \mathrm{e}$ \\
\hline $\mathrm{T}_{2}$ & $20.12 \pm 2.58 b c$ & $11.98 \pm 1.61 b c$ & $09.29 \pm 0.01 \mathrm{~d}$ \\
\hline $\mathrm{T}_{3}$ & $32.64 \pm 1.20 \mathrm{ab}$ & $19.69 \pm 0.21 \mathrm{ab}$ & $16.64 \pm 0.32 c$ \\
\hline $\mathrm{T}_{4}$ & $38.60 \pm 2.50 \mathrm{a}$ & $26.18 \pm 2.66 \mathrm{a}$ & $24.16 \pm 0.31 \mathrm{a}$ \\
\hline $\mathrm{T}_{5}$ & $35.76 \pm 4.91 \mathrm{a}$ & $20.82 \pm 2.12 \mathrm{ab}$ & $19.26 \pm 0.18 b$ \\
\hline F test & $*$ & $*$ & $*$ \\
\hline $\mathrm{CV} \%$ & 16.4 & 19.5 & 11.3 \\
\hline
\end{tabular}

Value represents mean \pm standard error of two independent experiments, each having three replicates.F test:- *: $\mathrm{p}<0.05$.

Means followed by the same letter in each column are not significantly different according to DMRT at 5\% level
Hlaing et. al., (1996) reported that bokashi with EM or FYM with EM produced comparable more yield and yield components to those of chemical fertilizer treatment hence, bokashi with EM and FYM was found to produce significantly superior yield to that of chemical fertilizer treatment in sugarcane. In present study, $\mathrm{T}_{4}$ exhibited greater mean performance for mature pod fresh $(38.6 \mathrm{~g})$ and mature pod dry weight $(26.18 \mathrm{~g})$ and dry seed weight $(24.16 \mathrm{~g})$ than $\mathrm{T}_{1}, \mathrm{~T}_{2}$, $\mathrm{T}_{3}$ and $\mathrm{T}_{5}$. This is due to high amount of potassium present in the goat manure. This was supported by numerous researches who reported that total yield, marketable yield; commercial fruit yield and total average yield per plant were increased by increasing application rates of potassium (Verma et al., 1991; Harneet et. al., 2003).

\section{Nutrient analysis of seeds}

\section{Moisture content (\%)}

Table V shows that there was significant difference $(\mathrm{P}<0.01)$ in the moisture content of seeds among the treatments. Moisture content of seeds ranged from $10.98 \%$ to $12.65 \%$ and vegetable cowpea which managed without fertilizer (T1) showed highest moisture content, the reason may be the low accumulation of food in seeds and high uptake of water by the plants due to lack of nutrients. Quass (1995) reported that moisture of cowpea is $11 \%$.

\section{Ash content (\%)}

It was observed that ash content of cowpea seeds were significantly varied $(\mathrm{P}<0.01)$ among the treatments $($ Table $\mathrm{V})$ and it ranged from $3.39 \%$ to $3.88 \%$. Important aspect of EM is that it enhances beneficial microbes in the soil, thereby developing a conductive environment for the crop (Kyan et. al., 1999). According to the results, crop fertilized with EMbokashi showed the slightly higher ash content than chemical fertilized crop. Among the EM-bokashi treatments, goat manure EM-bokashi $\left(\mathrm{T}_{4}\right)$ showed the highest ash content. This may be due to high amount of potassium in goat manure in the form of $\mathrm{K}_{2} \mathrm{O}$ because the major component of ash is $\mathrm{K}_{2} \mathrm{O}$.

\section{Protein content (\%)}

Table V shows that there was significant difference $(\mathrm{P}<0.01)$ in the protein content of vegetable cowpea seeds. Synthesis of proteins, metabolisms of carbohydrates and lipids and activation of numerous enzymes depend on potassium, because elemental form of potassium is required to energize at least 60 different enzymes, which take part in plant growth 
Shahardeen and Seran

Table V. Moisture, ash, protein and crude fiber contents of vegetable cowpea seeds

\begin{tabular}{ccccc}
\hline Treatments & Moisture (\%) & Ash (\%) & Protein (\%) & Crude fiber (\%) \\
\hline $\mathrm{T}_{1}$ & $12.65 \pm 0.01 \mathrm{a}$ & $3.39 \pm 0.01 \mathrm{~d}$ & $20.56 \pm 0.02 \mathrm{~d}$ & $6.08 \pm 0.02 \mathrm{e}$ \\
$\mathrm{T}_{2}$ & $12.06 \pm 0.01 \mathrm{~b}$ & $3.43 \pm 0.01 \mathrm{c}$ & $20.73 \pm 0.01 \mathrm{c}$ & $6.25 \pm 0.01 \mathrm{~d}$ \\
$\mathrm{~T}_{3}$ & $11.78 \pm 0.01 \mathrm{c}$ & $3.52 \pm 0.01 \mathrm{~b}$ & $20.82 \pm 0.01 \mathrm{~b}$ & $6.36 \pm 0.02 \mathrm{c}$ \\
$\mathrm{T}_{4}$ & $10.98 \pm 0.01 \mathrm{e}$ & $3.88 \pm 0.02 \mathrm{a}$ & $20.91 \pm 0.01 \mathrm{a}$ & $6.60 \pm 0.02 \mathrm{a}$ \\
$\mathrm{T}_{1}$ & $11.44 \pm 0.01 \mathrm{~d}$ & $3.86 \pm 0.01 \mathrm{a}$ & $20.82 \pm 0.01 \mathrm{~b}$ & $6.42 \pm 0.01 \mathrm{~b}$ \\
$\mathrm{~F}$ value & $* *$ & $* *$ & $* *$ & $* *$ \\
$\mathrm{CV} \%$ & 6.5 & 3.3 & 5.1 & 1.5 \\
\hline
\end{tabular}

Value represents mean \pm standard error of two independent experiments, each having three replicates.F test: $-* *: \mathrm{P}<0.01$.

Means followed by the same letter in each column are not significantly different according to DMRT at 5\% level

(Alam and Naqvi, 2001) and also it requires for every major steps of protein synthesis. With increasing potassium availability and uptake by the plant, the protein content of seeds increase that was the reason for higher protein content of seeds in goat manure EM-bokashi $\left(\mathrm{T}_{4}\right) . \mathrm{K}_{2} \mathrm{O}$ content of cattle manure, goat manure and poultry manure are $0.1 \%, 3 \%$, $1.5 \%$ (Inckel et. al., 2005) respectively.

\section{Crude fiber content (\%)}

Crude fiber content (\%) of vegetable cowpea seeds also showed significant difference $(\mathrm{P}<0.01)$ among the treatments (Table V). Fiber content of seeds ranged from 6.08\% to $6.60 \%$. Quass (1995) reported that crude fiber content of cowpea ranged from $5.95 \%$ to $7.3 \%$. Among the treatments plant managed without fertilizer showed lowest value in fiber content and plant fertilized with goat manure EMbokashi showed highest value. Mengel (1997) reported that potassium requires for the production of high-energy molecules (ATP). This promotes synthetic process in plant metabolism, resulting in production of carbohydrates, proteins, lipids and vitamins.

\section{Conclusion}

The present study indicates the significant influence of animal manure EM-bokashi on seed yield and quality of vegetable cowpea. Animal manures EM-Bokashi were suitable to achieve better seed yield. However, among the EMbokashi treatments, goat manure EM-bokashi is the best for obtaining high yield and better quality of vegetable cowpea.

\section{References}

Alam SM and Naqvi MH (2011), Potassium and its role in crop growth. Available online at http:/www. pakissan.com/english/advisory/potassium.crop.shtml.

Alex G (2009), Organic alternatives to chemical fertilizer. In: Catalyst Vol. I (Ed. A. Haimovich) University of Colorado. Colorado, USA. pp 33-40.
Ano AO (2006), Effect of vegetable cowpea population on component crop yields and productivity of yam, minisett based system. Nigerian J. Agric. 37: 81-84.

Anon. (1995), EM application manual for APNAN countries 1st edition. Asia-Pacific Natural Agriculture Network, Bangkok, Thailand. Available online at http://www. agriton.nl/apnanman.html/.

AOAC (2002), Official Method of Analysis (17th Edition). Association of Official Analytical Chemists, Washington, USA.

Chen JH (2008), The combined use of chemical and organic fertilizers and/or biofertilizer for crop growth and soil fertility. International workshop on sustained management of the soil-rhizosphere system for efficient crop production and fertilizer use. Taiwan: National Chung Hsing University. Available online at http://www. agnet.org/library/tb/174/.

Harneet K, Thakur JC and Neena C (2003), Effect of nitrogen and potassium on growth, yield and quality of tomato ((Lycopersicon esculentum mill.). cv. Punjab Upma. Haryana J. Horti. Sc, 32 (3/4): 286-288.

Hlaing WW, Kyaw TY, Lwin TH, Lwin,T., Oo KS, Thaung $\mathrm{T}$ and Yin H (1996), Effect of effective micro-organisms and organic amendments on crop production and on properties of cultivated soils. Thesis for B. Sc. (Agric.) degree, Institute of Agriculture, Yezin, Myanmar.

Hsieh SC and Hsieh CF (1990), The use of organic matter in crop production. Taichung District Agricultural Improvement Station, Taichung, ROC Taiwan. Extension Bulletin No. 315: 1-20.

Inckel M, Smet PD, Tersmette T and Veldkamp T (2005), The preparation and use of compost. Agrodox No. 8 (7th edition), Agromisa Foundation, Wageningen. 
Digigrafi, Wageningen, Netherland.

Iwaishi S (2000), Effect of Organic Fertilizer and Effective Microorganisms on Growth, Yield and Quality of Paddy-Rice Varieties. Crop Prod. 3 (1):269 - 273.

Javaid A, Bajwa R and Siddiqi I (1999), EM and VAM Technology in Pakistan. VI: Effect of EM on VA mycorrhizal development and subsequent crop growth and yield in sunflower. Pakistan J Biol Sci. 2: 586-589.

Khaliq A, Abbasi MK and Hussain T (2006), Effect of integrated use of organic and inorganic nutrient sources with effective microorganisms (EM) on seed cotton yield in Pakistan. Biores. Tech. 97: 967-972.

Kyan T, Shintani M, Kanda S, Sakurai M, Ohashi H, Fujisawa A and Pongdit S (1999), Kyusei nature farming and the technology of effective micro organisms. International Nature Farming Research Center (INFRC), Atami, Japan and Asia Pacific Natural Agriculture Network (APNAN), Bangkok, Thailand.

Langyintuo AS, Lowenberg-DeBoer J, Faye M, Lambert D, Ibro G, Moussa B, Kergna A, Kushwaha S, Musa S and Ntoukam G (2003), Cowpea supply and demand in West Africa. Field Crops 82: 215-231.

Mengel K (1997), Impact of potassium on crop yield and quality with regard to economical and ecological aspects. In: Food Security in the WANA region, the essential need for balanced fertilization (Ed: A.E. Johnston). Proceedings of the Regional Workshop of the International Potash Institute held at Bornova, Izmir, Turkey, 26-30 May 1997. IPI, Bern, Switzerland. pp. 157-174.

Milev G and Genchev D (1996). Nodule formation ability of common bean (Phaseolus vulgaris L.) cultivars. Acta Hort 462 (2): 857-862.

Moller K (2009), Influence of different manuring systems with and without biogas digestion on soil organic matter and nitrogen inputs, flows and budgets in organic cropping systems. Nutr Cycl Agroecosyst 84: 179-202.

Myint CC (1991), Nature Farming in Myanmar. Proceeding of First International Conference on Kyusei Nature Farming, Oct. 17-21, 1989, Khon Kaen., Thailand.

Omueti O, Ojomo OA, Ogunyanwo O and Olafare S (2008), Biochemical Components and Other Characteristics of Maturing Pods of Vegetable Cowpea (Vigna unguiculata). Research Article of Cambridge University 22: 25-32.
Premaratne KP and Oertli JJ (1994), The influence of potassium supply on nodulation, nitrogenase activity and nitrogen accumulation of soybean (Glycine max L.). Nutr Cycl Agroecosyst 38: 95-99.

Quass CF (1995), Guidelines for the Production of Cowpeas. National Department of Agriculture, Pretoria. South Africa. Pp 1-17.

Ross HM (2005), Managing Livestock Manure. Published by the Alberta Agriculture and Rural Development, Alberta, Available online at http//www1.agric.gov. ab.ca/\$department/deptdocs.nsf.

Samina E, Asghari B and Syed A (2008), Effect of EM, Rhizobium and PSM alone and combination on the yield of Radish (Raphanus sativus L.). Quaid-e-Azam University, Islamabad, Songo sangyo co., Ltd, okinawa, Japan.

Sangakkara UR, Weerasekera DN, Attanayake KB and Attanayake AMU (2008), Inoculation affects nitrogen balances of composts and growth, yield and microflora of Phaseolus beans. In cultivating the future based on science. Proceedings of Second Scientific Congress of ISOFAR, Modena, Italy. (Ed. D. Neuhoff et. al,) Germany: 102.

Sanginga N, Mulongoy K and Ojeifo AA (1994), Persistence and recovery on induced Rhizobium ten years after inoculation on Leucaena leucocephala grown on an Alfisil in South western Nigeria. Plant soil 159: 199-204.

Stolze M, Piorr A, Häring AM and Dabbert S (2000), Environmental Impacts of Organic Farming in Europe: Economics and Policy (Vol. 6). Universität Hohenheim. Stuttgart, Germany.

Verma SK, Singh SS and Awasthi CP (1991), Effect of potassium fertilization on the yield and quality of tomato (Lycopersicon esculentum mill.). Progressive horticulture.1991 publ., 1993; 23(1-4):110-113.

Winget R and Gold RS (2007), Effect of effective microorganisms on the growth of Brassica rapa. Brigham Young University of Hawaii, Bio 493 Yuka Nakano, Hawaii.

Yan $\mathrm{P}$ and $\mathrm{Xu} \mathrm{H}$ (2002), Influence of EM Bokashi on Nodulation, Physiological Characters and Yield of Peanut in Nature Farming Fields. J Sust Agric. 19(4): 105-112.

Received: 10 April 2011; Revised: 20 March 2013, Accepted: 24 March 2013. 